\title{
Bryophytes as key indicators of ecosystem function and structure of northern peatlands
}

\author{
DALE H. VITT ${ }^{1} \&$ MELISSA HOUSE ${ }^{1}$ \\ ${ }^{I}$ School of Biological Sciences, Southern Illinois University, Carbondale, IL, 62901, U.S.A., \\ "="dvitt@siu.edu; @ ittps://orcid.org/0000-0002-7808-3964 \\ "=mhouse@siu.edu; @ ittps://orcid.org/0000-0002-7635-9541
}

\begin{abstract}
Bryophytes play a number of important roles in the functioning and structure of northern peatlands where they form the ground layer of fens and bogs. Sphagnum, dominant in bogs and poor fens, and brown mosses, dominant in rich fens, make up a large percentage of the organic matter that is stored as deep deposits of peat. In this paper we review the mechanisms of resistance to decay in these two moss groups. We then document a case study of a rich fen dominated mostly by Hamatocaulis vernicosus, that has remained stable for over 8000 calendar years. At this site, we use macrofossil abundances, including bryophyte habitat positions on water level and chemistry gradients, to infer past environmental conditions. Lastly, we provide a new ecohydrologic framework for wetland classes centered on bryophyte abundances across water level, nutrient, and salinity gradients and argue that bryophyte species are among the most significant indicators for classifying wetland site-types.
\end{abstract}

Key words: Bog, bryophyte, community stability, ecohydrology, fen, Hamatocaulis vernicosus, moss, peatland classification

\section{Introduction}

Bryophytes are small plants that are abundant and dominate in only a few terrestrial ecosystems. In many forests with deciduous trees, bryophytes are restricted to areas free of litter (Startsev et al. 2008), while wetlands with dense graminoid cover restrict bryophytes to small, high microtopographic areas (Caners \& Lieffers 2014). There are, however, a few ecosystems wherein bryophytes form a continuous ground layer. These include high elevation tropical forests (Richards 1984), boreal coniferous forests (Esseen et al. 1997), arctic fens (Pouliot et al. 2009), and boreal and subarctic peatlands where they occupy $90-100 \%$ of the ground cover and play a significant role in the carbon and nitrogen budgets (Bond-Lamberty et al. 2004).

Among terrestrial ecosystems, peatlands sequester carbon over long millennial time scales more efficiently than any other. Northern peatland ecosystems cover approximately 4.23 million $\mathrm{km}^{2}$ or $2.84 \%$ of global land area (Xu et al. 2018), but store about 30\% of the global terrestrial carbon (Yu et al. 2010) and 10\% of the global soil nitrogen stock (Loisel et al. 2014). Boreal forests cover about one-third of the global forested area, with peatlands occupying approximately one-third of the boreal forest region (Wieder et al. 2006). Over the past 11700 years or so (the Holocene), these peatland ecosystems have played a significant role in the global carbon budget as sinks for atmospheric carbon and sources of methane to the atmosphere. Carbon and nitrogen are stored in organic matter that accumulates when net primary production exceeds organic matter decomposition leading to deposits of incompletely decomposed organic matter, or peat.

The accumulation of organic matter is dependent on a number of factors, of which the most important is the development of an anaerobic zone (or catotelm) that dramatically slows the decomposition of organic matter. However, other factors are also important in accumulation of organic matter, including acidity, plant resistance to decay, water retention, nutrient limitations, and restriction of the aerobic area to a narrow surface zone (the acrotelm). One of the characteristic features of boreal and subarctic peatlands is the pronounced abundance of bryophytes that occupy the ground surface and form the architecture of the peatland surface from which vascular plants establish and grow (Vitt 
2006, Pouliot et al. 2011). The abundance of these small plants in peatlands has long been overlooked where Sphagnum attains plant densities of 45000-60000 plants per $\mathrm{m}^{2}$ in bogs (Vitt et al. 2020) and brown mosses up to 318,000 plants per $\mathrm{m}^{2}$ in arctic fens (L. Rochefort pers. comm.). The vascular plants form structurally important layers, produce less biomass (Campbell et al. 2000), and decompose more readily compared to the bryophyte-dominated ground layer (Moore 1989).

Here we demonstrate the importance of bryophytes to the structure and function of northern peatlands. In parts 1 and 2 we examine how bryophytes influence peatland functioning and in sections 3 and 4 we utilize bryophytes to better understand how peatlands are related to environmental gradients. In particular, we present 1) a review of the characteristics of bryophytes that are important to organic matter accumulation, 2) a case study of how bryophytes are influential in the development of boreal fens and how bryophytes may influence the stability of peatlands at a millennial scale, 3) an approach using the presence of macrofossils, including bryophytes, in the peat column to infer historical environmental change within peatlands, and 4) an ecohydrologic framework for wetland classes centered on bryophyte responses to broad scale gradients.

\section{A review of characteristics of bryophytes that are important to organic matter accumulation}

It has long been known that species of Sphagnum are resistant to decomposition, and often compose a high percentage of the accumulated organic matter in bogs (Kuhry \& Vitt 1996). There are a number of possible reasons for this slow rate of decomposition including low phenol oxidase activity leading to the build-up of phenolics that inhibit decomposition (Freeman et al. 2001). Among the most obvious are the unique properties of species of the genus, including the very low concentration of nitrogen $(\mathrm{N})$ (Table 1) that averages about $50 \%$ or less of the total tissue $\mathrm{N}$ compared to brown mosses and vascular plants. Comparatively, the amount of carbon (C) in Sphagnum tissues is similar to that of brown mosses and vascular plants (Table 1), but the low amounts of $\mathrm{N}$ result in very high $\mathrm{C} / \mathrm{N}$ ratios, about twice those of other peat structural components (Table 1).

Sphagnum plant tissue is composed of large, dead, porose, hyaline cells intermixed with much smaller, non-porose, living cells-the latter are the only cells with cytoplasm, and this structural matrix of Sphagnum stems, branches, and leaves retain high $\mathrm{C}$ amounts in both the hyaline and living cells, with greatly reduced $\mathrm{N}$ that is contained only in the living photosynthetic cells. Rates of decomposition are much reduced owing to deficiencies in $\mathrm{N}$. The $\mathrm{N}$ limitation (in part yielding low quality litter) coupled to the strong acidity (some of which is procured by the inorganic acidity of the cation exchanger of Sphagnum cell walls Hemond 1980) allows organic matter to be accumulated in the peat profile. Comparably, rich fen plant communities dominated by brown mosses and graminoids, have similar $\mathrm{C}$ contents, but much higher $\mathrm{N}$ (Table 1), leading to higher rates of decomposition of high quality litter. In rich fens this litter is derived from graminoids, leaving low quality litter from brown mosses as a dominant component in the peat column. Brown mosses typically possess leaves with thick-walled linear cells having small lumens and little cytoplasm that provide lower amounts of labile cell contents and greater amounts of recalcitrant lignin-like compounds that are concentrated in peat by decomposition (Williams et al. 1998). Overall in western Canada, rates of organic matter accumulation have strong controls from environmental inputs, but both Sphagnum-dominated fens and brown moss-dominated fens accumulate peat at an average rate of $33.2 \mathrm{~g} \mathrm{C} \mathrm{m}^{-2} \mathrm{yr}^{-1}$ (Yu et al. 2014). Sphagnum-dominated systems have somewhat greater rates averaging $40.6 \mathrm{~g} \mathrm{C} \mathrm{m}^{-2} \mathrm{yr}^{-1}$ compared to $30.9 \mathrm{~g} \mathrm{C} \mathrm{m}^{-2} \mathrm{yr}^{-1}$ for brown moss-dominated rich fens (Yu et al. 2014).

TABLE 1. Properties of peat in northern peatlands. Data (means) from Loisel et al. (2014).

\begin{tabular}{llll}
\hline & Herbaceous & Brown moss & Sphagnum \\
\hline Bulk Density $\left(\mathrm{g} \mathrm{cm}^{3}\right)$ & 0.118 & 0.177 & 0.076 \\
Organic Matter Content (\%) & 85.6 & 81.4 & 94.3 \\
Carbon (\%) & 50.5 & 47.9 & 46.0 \\
Nitrogen (\%) & 1.7 & 1.4 & 0.7 \\
C/N ratio & 34.4 & 42.9 & 81.0 \\
\hline
\end{tabular}

In summary, northern peatlands accumulate large stores of organic matter (and carbon) mostly due to the presence of decay resistant bryophytes. Acidic peatlands dominated by Sphagnum accumulate organic matter due to low N concentrations limiting decomposition, but have low bulk densities, whereas rich fens dominated by brown mosses 
(and graminoids in many cases) accumulate organic matter due to high quality litter from graminoids coupled to low quality litter from brown mosses that produce peats with high bulk densities and high $\mathrm{N}$.

\section{A case study of how bryophytes are influential in the development of boreal fens and how bryophytes may influence the stability of peatlands at a millennial scale}

Hamatocaulis vernicosus (Mitt.) Hedenäs is a pleurocarpous moss (Bryophyta, Bryopsida-Goffinet et al. 2009) and member of the Calliergonaceae (Hedenäs 2008). Morphologically, it is distinguished by large, irregularly pinnate plants; stems with a hyalodermis, and leaves that are broadly ovate-lanceolate, acuminate, and falcate-secund. The leaves have a costa ending about mid-leaf, medial and distal cells linear in shape with thick-walls and narrow lumens. The species is easily recognized by having characteristic fish-hooked branch tips (Vitt \& Lüth 2017). Ecologically, it occurs in calcareous wetlands and lake shores and has been considered a characteristic species of moderate-rich fens (Vitt \& Chee 1990). The species occupies wet hollows, lawns, and flarks. When occurring in lawns and flarks it grows erect to ascending forming dense, pure populations. The species is found across boreal and subarctic Eurasia and North America, southward to Oregon in the west and Illinois, Ohio, and Indiana in the east and is disjunct in the West Indies and northern South America (Hedenäs 2008).

Rich fens occur scattered across the northern hemisphere in areas with circumneutral or alkaline ground water. In North America, these calcium-rich fens are frequent on the landscape in continental western Canada from the Rocky Mountains eastward and become increasingly uncommon in central Canada-an area influenced by the acidic rocks of the Canadian Shield. Historically in western Canada, rich fens have been documented to initiate in the Mid-Holocene somewhat after the retreat of glaciers and following on to the Early Holocene dry period that extended to around 7,000 cal yr BP (Kubiw et al. 1989, Kuhry et al. 1992, Yu et al. 2003). Some of these fens have continued to exist for long periods of time ( $\mathrm{Yu}$ et al. 2003) while at other sites, autogenic succession has occurred giving rise to more acidic peatland site-types such as poor fens and bogs. (Kuhry et al. 1993). Here we report on the occurrence of Hamatocaulis vernicosus in a rich fen in northeastern Alberta.

Study Site: McClelland Lake and its associated patterned fen is located in northeastern Alberta, Canada

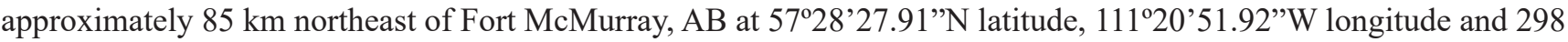
$\mathrm{m}$ elevation. McClelland Fen and the surrounding wetland complex is 3481 ha in area and approximately $10 \mathrm{~km}$ long and $5 \mathrm{~km}$ wide at its widest point. The patterned portion of the complex is 899 ha in area (Vitt et al. 2003). The flarks are largest near to the lake and gradually decrease in size westward and away from the lake with water flow eastward. Flarks are dominated either by Hamatocaulis vernicosus or Scorpidium scorpioides, along with vascular plants Carex diandra and C. lasiocarpa. The strings, when well developed, have a tree cover of Larix laricina. Less developed strings are dominated by the shrub, Betula glandulifera. Other vascular plants that are common are Carex chordorrhiza, Menyanthes trifoliata, and Triglochin maritima. The moss, Tomentypnum nitens forms large mounds on the strings. Other bryophytes found infrequently in the fen include Aulacomnium palustre, Meesia triquetra, Pseudocalliergon trifarium, and Ptychostomum pseudotriquetrum (Vitt et al. 2003).

Methods: The Holocene history of the fen was investigated by extracting $15-\mathrm{cm}$ diameter peat cores using a vibrating corer that extracts $2-\mathrm{m}$ long core segments. The peat core reported on here was extracted from a flark $\left(57^{\circ} 28^{\prime} 05.20^{\prime \prime} \mathrm{N}, 111^{\circ} 24^{\prime} 19.50^{\prime \prime} \mathrm{W}\right)$, placed in $15 \mathrm{~cm}$ PVC pipe (cut lengthwise for access), frozen, shipped to the laboratory, and kept cold at $2^{\circ} \mathrm{C}$. Some compaction was evident at 200,315, and $460 \mathrm{~cm}$ depths. Samples approximately one $\mathrm{cm}^{3}$ were extracted from the center of the core at every $4 \mathrm{~cm}$ for the length of the core. These samples were examined under a dissecting microscope and percent debris (tiny unrecognizable organic particles) and macrofossil content estimated, following this the sample was rinsed above a 1-mm sieve and the contents again examined under a dissecting microscope. All macrofossils were identified as follows: first, percent estimates (based on 100\%) were recorded for the structural component (sum of graminoids, roots, leaves, wood, bark, bryophytes, needles, charcoal, mineral). Secondly, the abundances of all bryophyte species were estimated (based on $100 \%$ of bryophytes present). Material for radiocarbon dating was extracted at distinct stratigraphic intervals and at the peat-mineral contact and sent to DirectAMS, Bothell, WA, U.S.A. Calibrations (cal. yr BP) were based on intCal109 calibration dataset (Reimer et al. 2009). Dates of 8700 and 9100 years were interpolated from bracketed calibrated dates.

Results: Organic material at $730 \mathrm{~cm}$ depth (dated at $11457 \mathrm{cal} \mathrm{yr} \mathrm{BP)} \mathrm{contained} \mathrm{abundant} \mathrm{woody} \mathrm{twigs} \mathrm{with}$ lesser amounts of graminoids, and no bryophytes. Just above this organic stratum, a $24 \mathrm{~cm}$ wide zone (dated at 231 years) of sandy mineral sediments is present. These zones suggest a moist post-glacial landscape, with at first shrubs, succeeding to a wet graminoid meadow. The first peat-forming community (at $11226 \mathrm{cal} \mathrm{yr} \mathrm{BP}$ ) was dominated by graminoids and shrubs and few bryophytes, suggesting a wet meadow environment formed on wet sand. Also contained 
in these sediments are high percentages of debris that suggest relatively high rates of decomposition and limited peat accumulation. This period of early wetland development is associated with deglaciation of the area, dated at $11250 \mathrm{cal}$ yr BP (Fisher et al. 2009). This time period is also associated with the Lake Agassiz-Clearwater/Athabasca River flood that began at $11275 \mathrm{cal} \mathrm{yr} \mathrm{BP}$. The flood discharged $22000 \mathrm{~km}^{3}$ of water into the Arctic Ocean over a 1.5-3.0 year period, with continued flow until $10750 \mathrm{cal}$ yr BP. It may have been the cause of the abrupt climate cooling period (Preboreal Oscillation) that occurred at $11300 \mathrm{cal} \mathrm{yr} \mathrm{BP,} \mathrm{lasting} \mathrm{for} \mathrm{150-350} \mathrm{years} \mathrm{(Fisher} \mathrm{et} \mathrm{al.} \mathrm{2002).} \mathrm{The} \mathrm{Lake} \mathrm{Agassiz} \mathrm{flood}$ channel is present just south of the location of the fen, with the fen location itself not inundated with water. About 500 years later, eutrophic bryophytes became dominant (Calliergon giganteum and Drepanocladus aduncus) indicating a freshwater marsh community and after another 400 years (about $10400 \mathrm{cal} \mathrm{yr} \mathrm{BP)} \mathrm{Hamatocaulis} \mathrm{vernicosus} \mathrm{became}$ dominant, with some remaining shrub presence. At about $9100 \mathrm{cal}$. yr BP shrubs decrease and Scorpidium scorpioides was present for a short period, along with $H$. vernicosus. After $8700 \mathrm{cal} \mathrm{yr} \mathrm{BP,} \mathrm{this} \mathrm{latter} \mathrm{species} \mathrm{remained} \mathrm{dominant}$ throughout the core until the present time.

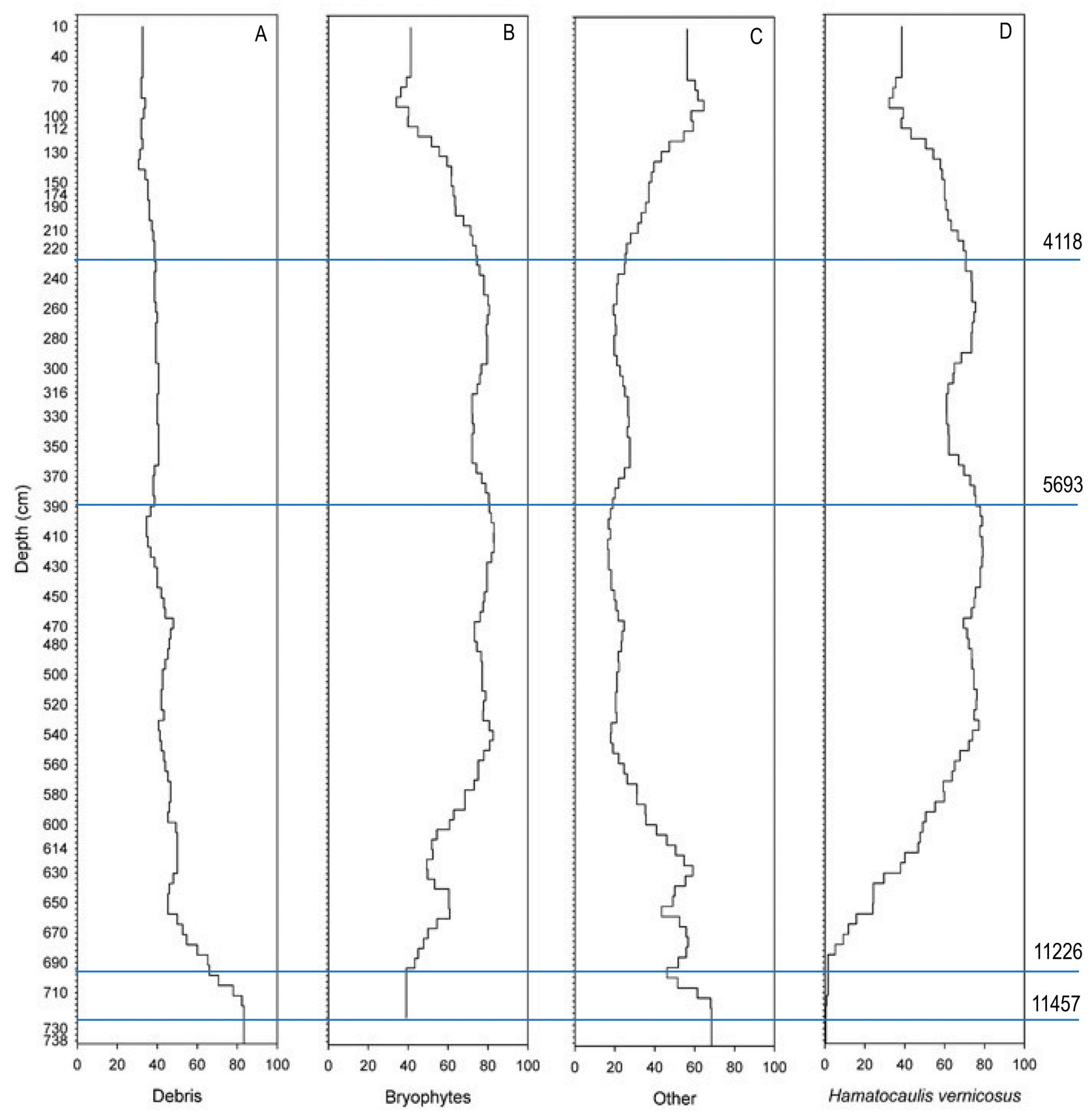

FIGURE 1. Summarized abundances (\%) of macrofossil components of $738 \mathrm{~cm}$ long core from McClelland Wetland. Values are 5-sample running means plotted along core depth $(\mathrm{cm})$. A. Debris. B. Bryophytes C. Summed other macrofossils. D. Hamatocaulis vernicosus. Dates are cal yr BP. 
Two additional radiocarbon dates at 5693 and $4118 \mathrm{cal} \mathrm{yr} \mathrm{BP}$ provide the basis for calculating peat accumulation rates during the Holocene. Overall, accumulation of organic matter for the site was $0.062 \mathrm{~cm} \mathrm{yr}^{-1}$ but varied from 0.056 to $0.055 \mathrm{~cm} \mathrm{yr}^{-1}$ in the Early and Late Holocene to $0.103 \mathrm{~cm} \mathrm{yr}^{-1}$ in the mid Holocene.

Structural Components: Debris accounted for $44.6 \%$ ( \pm 1.4 standard error [S.E.]) of the peat materials with only a slight increase with depth (Fig. 1A). Bryophytes composed a majority of the structural components of the core (averaging $65.2 \% \pm 2.1$ S.E., Fig. 1B), with graminoids, shrubs, and woody materials (35.1\% \pm 2.1 S.E., Table 1C) of less abundance. Among the bryophytes, H. vernicosus is dominant through nearly the entire core representing $90.5 \%$ ( \pm 1.5 S.E., Table 1D) of the bryophyte component.

Discussion: The long-term ecological stability of this site, dominated by a single species of bryophyte, remained essentially unchanged for about $8700 \mathrm{cal}$. years. The continued persistence of Hamatocaulis vernicosus at the site as demonstrated in this core may make this species one of the longest continuous occurrences of a species (and almost certainly one of the oldest living plants-as new living growing parts of peat-forming bryophytes extend upward from their decomposing lower portions). Although many if not most bogs found on the present-day landscape originated through rich fen paludification, (Kuhry et al. 1993), in cases where there is a source of ground water with uniform quality, rich fens can persist for millennia and form the most stable of all terrestrial plant communities. Similar longterm persistence has been reported for a rich fen in the western Alberta dominated by Scorpidium scorpioides (Yu et al. 2003).

\section{Utilization of macrofossils to infer historical environmental change within peatlands}

The common peatland bryophytes exhibit clearly circumscribed habitat requirements, and their positions along water level and chemical gradients are well documented (Bauer et al., 2003; Gignac et al. 1991a, b, Gorham \& Janssens 1992, Sjörs 1983) and provide the defining attributes of peatland site-types. Bryophyte habitat tolerances in northern fens are closely tied to water level and hydrochemistry, whereas vascular plant abundances are more closely related to nutrient availability (Vitt and Chee 1990). Quantifying these gradient positions allows paleoenvironmental conditions to be reconstructed in detail along stratigraphic profiles obtained from cores. Indicator values and tolerance ranges for depth to water table, selected cation concentrations $\left(\mathrm{Ca}^{+2}\right.$ and $\left.\mathrm{Mg}^{+2}\right)$ were calculated for each macrofossil taxon from a large dataset for western Canada (Gignac et al. 1990a, Bauer et al. 2003) or from a local training set based on data obtained from a 2018 water sample collection from 64 plots across McClelland Fen. Water table values were $\log$ transformed, and all taxon indicator values and tolerance ranges were calculated from the resulting distributions by weighted averaging (Birks et al. 1990). Values of environmental variables were inferred for water level and sum of divalent base cations, using transfer functions derived from Birks et al. (1990) and plotted as running means using 0.10 sampling proportion along the core lithology. Transfer functions that have included bryophytes have been used in western Canadian boreal peatlands to develop inferred past environments by Bauer et al. (2003), Kuhry et al. (1992) and Nicholson and Vitt (1994), in sites from the Red Lake peatlands in northern Minnesota (Janssens et al. 1992), and in arctic fens (Ellis et al. 2006)

Here we show inferred variation for water levels (Fig. 2A) and calcium+magnesium concentrations in surface water (Fig. 2B - as key components of salinity for rich fens - (Vitt and Chee 1990). At initiation of organic matter, water depths increased from 18-20 cm below the soil surface to $11-14 \mathrm{~cm}$ below the surface at $\pm 700 \mathrm{~cm}$ depth during the short marsh phase, then decreased in the early Holocene during rich fen initiation to $15-16 \mathrm{~cm}$ below the surface, finally becoming stable (continuing to the surface at $11-12 \mathrm{~cm}$ below the surface. The $\mathrm{Ca}^{2+}+\mathrm{Mg}^{2+}$ was $35-40 \mathrm{mg} \mathrm{L}^{-1}$ at initiation, increased to about $50 \mathrm{mg} \mathrm{L}^{-1}$ during the marsh phase, and beginning at $630 \mathrm{~cm}$ depth stabilized to $62-70 \mathrm{mg}$ $\mathrm{L}^{-1}$ throughout the rich fen phase, and remained relatively constant to the present day.

\section{An ecohydrological framework for wetland classes centered on bryophyte responses to broad scale gradients}

The division of peat-forming wetlands into first, bogs and fens, and secondly into several types of fens has long been recognized across the world. The beginnings of peatland classification probably are derived from Weber (1911) wherein he argued that the source of the water arriving at a peatland will be influential in its vegetation and functioning. He used the terms Hochmoore (or bogs) for sites that received all of their water from the atmosphere (ombrogenous) and Niedermoore for sites that receive additional waters from the surrounding landscape (minerogenous). In the 1940's, Heinar DuReitz $(1942,1954)$ recognized floristic patterns in the fens of Sweden, and somewhat later Hugo Sjörs $(1950,1952)$ associated surface water chemistry with these floristic ones proposing rich fen and poor fen categories 


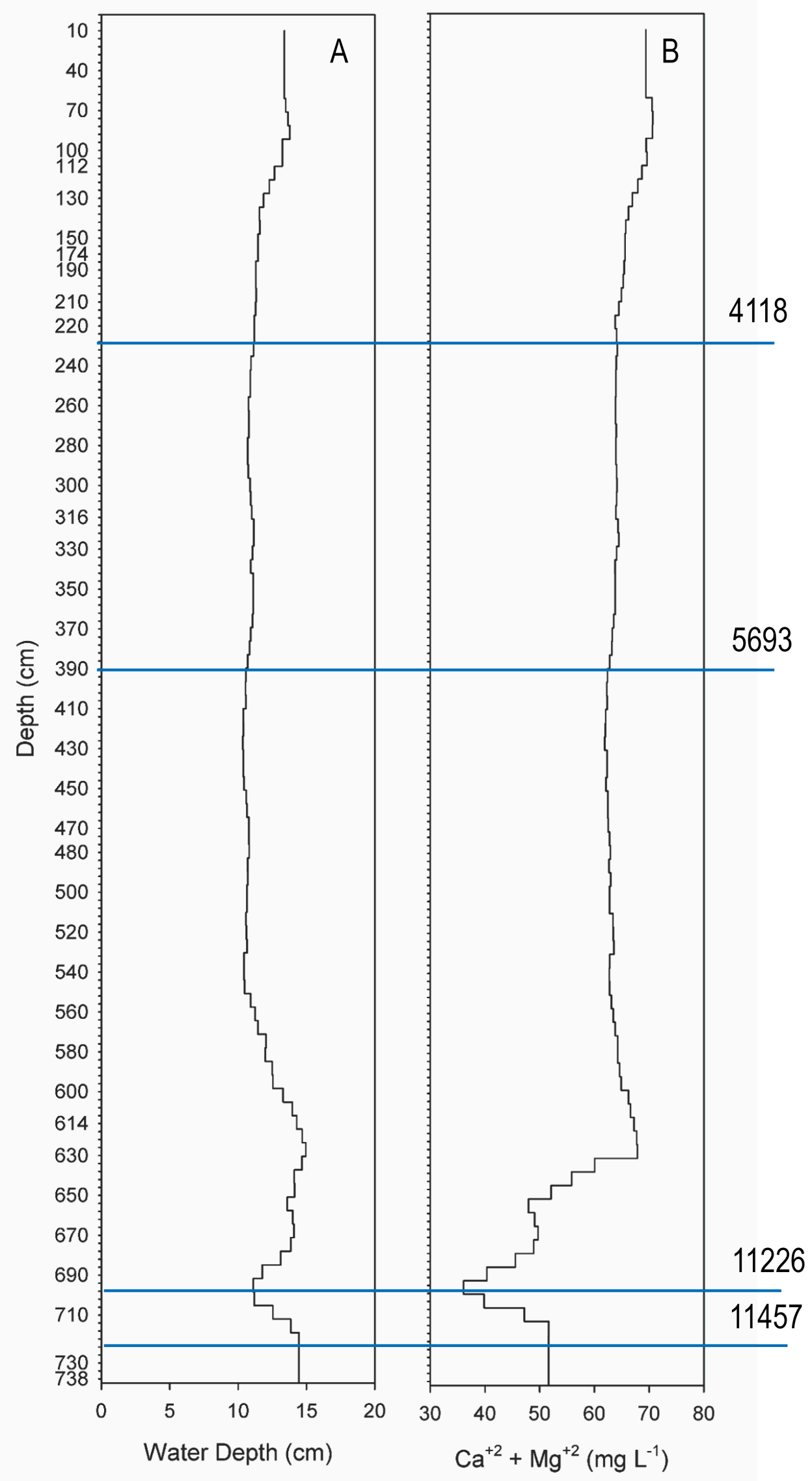

FIGURE 2. Inferred variation in environmental factors along the $738 \mathrm{~cm}$ long core from McClelland Wetland. A. Water depth below soil surface. B. Summed $\mathrm{Ca}^{2+}+\mathrm{Mg}^{2+}$ concentrations in surface water. Dates are cal yr BP. 
for sites 'rich' in indicator species as opposed to sites 'poor' in indicators. Bryophytes played an important role in classifying sites into either rich or poor fens because many (perhaps most) of the indicators were species of bryophytes, with these species having high fidelity to particular sets of water chemistries. Using $\mathrm{pH}$ and electrical conductance (as a measure of total cations and anions, or salinity), Sjörs (1950) proposed that rich fens could be divided into two typestransitional rich fens (later modified to moderate-rich fens) and extreme-rich fens. Unfortunately, over the decades since, the use of these terms has not always followed the definitions and use intended by the original authors. The terms rich and poor have been used to mean rich in nutrients, rich in ions, or rich in species diversity, or mis-applied because only vascular plants were utilized in site classification. Although Sjörs' original classification was organized around the association of flora and chemistry, he identified his fen types based on indicators from the former. Here we argue that these peatland types, as well as non-peat forming wetland types, are best identified by the use of bryophyte structural groups and in some cases specific species, and that an ecohydrologic framework for a unified wetland classification should use bryophytes as important structural indicators.

In addition to peat-forming fens and bogs, boreal wetlands also include ecosystems that accumulate less peat over long spans of time (generally defined as less than 30 [or 40] $\mathrm{cm}$ in depth). These non-peat forming wetland site-types can be quite similar in some features to peat forming site-types. In North America, graminoid site-types have in general been called marshes, whereas site-types with woody vegetation (greater than $25 \%$ cover of shrubs and/or trees) have been recognized as swamps.

\section{An Ecohydrologic Framework}

As water flows on and through the landscape, it is altered by interactions with vegetation and soil. These allogenic hydrological inputs control to a large extent the initiation and early development of wetlands. Especially significant are water flow, nutrient inputs, and base cation/anion concentrations (salinity). As peatlands develop over time, the importance of these allogenic factors is variably replaced by internal (or autogenic) controls. Sites on the landscape with variable water levels and eutrophic nutrient contents provide conditions for marshes when the site is inundated or swamps (with high levels of seasonal inundation and periodic drier conditions). Sites having more constant inputs of water with less nutrient inputs but high base cations are colonized by rich fen plants, or if water has a high concentration of sodium then brackish or sodic wetlands are initiated. Sites with acidic water inputs develop poor fens colonized by Sphagnum. As wetlands develop, the vegetation asserts greater control: water levels may be modified and maintained by the ground layers, site chemistry may be modified by the ground layer, and the developing organic column functions to create anaerobic soil conditions allowing for more organic matter accumulation. This accumulation of organic matter may remove the living vegetative surface farther from the influences of mineral water reducing nutrient availability. These interactions of ecology and hydrology provide the basis for differentiating wetland site-types, with the bryophyte-dominated ground layer central to varying wetland functions.

Three ecohydrologic gradients influence wetland development and status. Wetness of the site, nutrient availability at the site, and composition of salinity form the basis of our Framework of Wetland Classification (Fig. 3A-C).

\section{Bryophytes: Structural indicators in site-type recognition}

The four wetland classes (plus shallow open water) proposed by CCELC (1988) were placed in a functional framework that linked wetland types to environmental gradients by Vitt (1994). In this framework, bogs and fens differ along base cation and $\mathrm{pH}$ gradients, with these differing from swamps and marshes along nutrient and water level fluctuation gradients. Saline wetlands were included, but not discussed. However, as we have begun to better understand the variation present in these wetland classes, it became apparent that significant vegetative characteristics, especially those influenced by bryophytes, added much to the criteria of classification (Vitt 2006).

The four wetland classes have in general been recognized as basic to wetland classification (Fig. 3A, CCELC 1988), and here we bring these together into a unified ecohydrologic framework (Fig. 3B). Gorham and Janssens (1992) identified the importance of bryophytes and how various taxonomic groups related to site chemistry. Wheeler and Proctor (2002) and Bridgham et al. (1996) also have proposed terminology that considered bryophyte structural groups as important parts of their terminology, but did not link peatlands to non-peat forming wetlands. Bryophyte structural types contribute in a significant manner to the allogenic development and functioning of wetland ecosystems, especially to the accumulation of peat, site productivity, and responses to environmental disturbances. Individual species are key to identifying wetland types and provide the basis for many functional attributes of wetlands that can be used in restoration, estimates of carbon stores, and carbon accumulation. Variation within each of the four wetland classes are described as follows. 

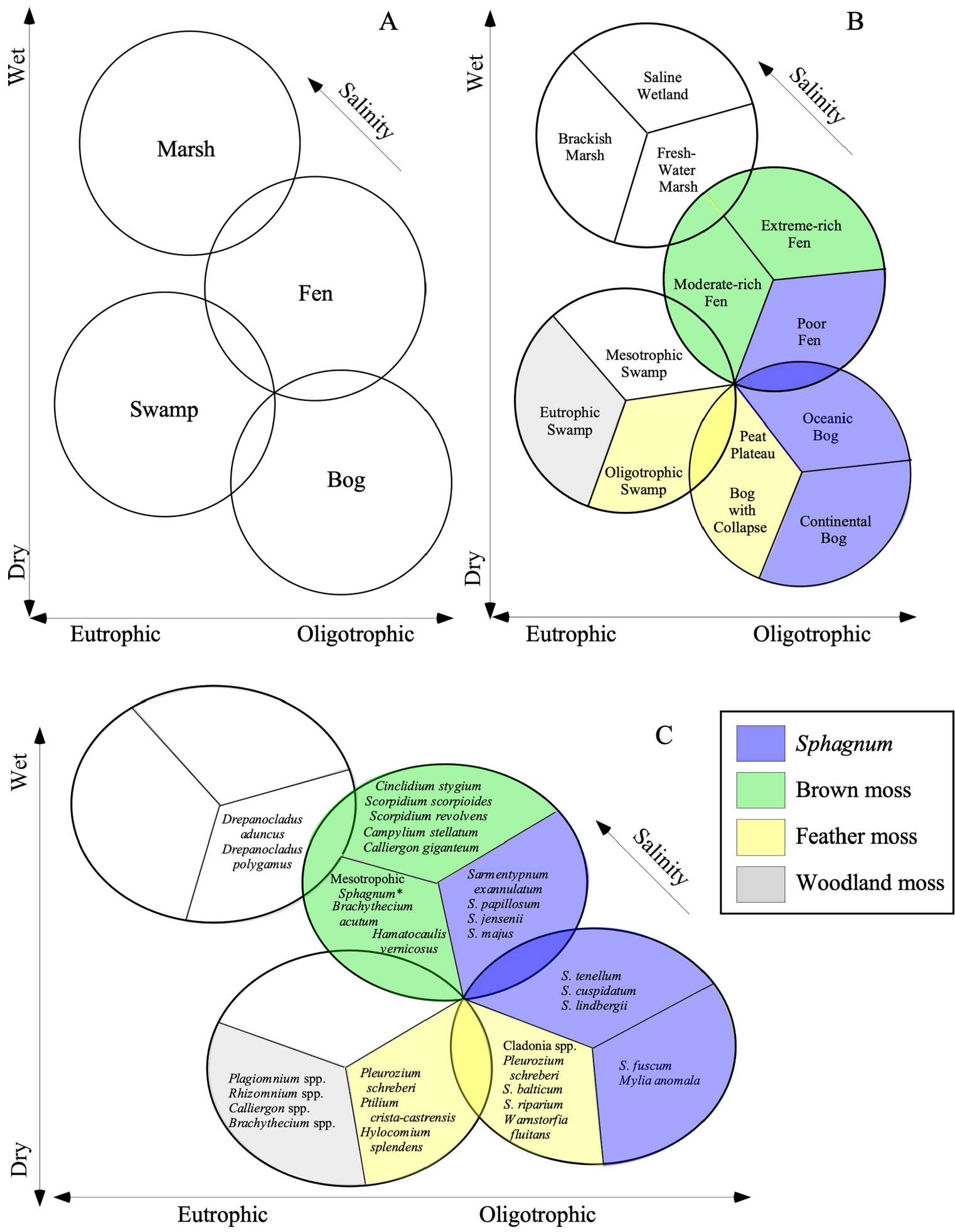

FIGURE 3. Framework and characteristic bryophytes for the wetland site-types related to the 4-class wetland classification. A. Traditional 4-class wetland classification plotted against trophic (nutrient) status, wetness, and salinity gradients. B. Bryophyte distribution plotted on the four wetland classes. Blue=acidic, Sphagnum-dominated peatlands; Yellow=Treed, feather moss-dominated, non-peat-forming wetlands; Green=circumneutral to alkaline, brown moss-dominated peatlands; Grey=riparian non-peat-forming wetlands with terrestrial woodland bryophytes; White=non-peat-forming wetlands with occasional bryophytes present or no bryophytes. Saline wetlands have high sodium (=sodic wetlands). C. Examples of indicator species of bryophytes for the wetland site-types. Indicators selected from Canadian wetlands (Vitt 2014), but hold true for Eurasian wetlands. S=Sphagnum. Feather moss=Pleurozium schreberi, Hylocomium splendens, and Ptilium crista-castrensis; Brown moss=any number of dark-colored members of true mosses (Bryopsida) inhabiting peatlands. Sitetype (Cajander 1913) a distinctive set of wetland sites with specific vegetative, floristic, soil, and physical characteristics. Bryophyte nomenclature follows (BFNA 2007, 2014). 
Marshes: Graminoid or forb (Typha spp.) plant communities on shallow (or sometimes deep) peat deposits, with few or no bryophytes. Sodic wetlands have high $\mathrm{Na}^{+}$concentrations (electrical conductance [EC] $>45000 \mu \mathrm{S} \mathrm{cm}^{-1}$ ) and bryophytes are absent and graminoids are not abundant. Characteristic species may include Triglochin maritima, Calamagrostis inexpansa, and Juncus balticus. Brackish marshes have intermediate levels of $\mathrm{Na}^{+},(\mathrm{EC}=2000-15000$ $\mu \mathrm{S} \mathrm{cm}^{-1}$ ), no bryophytes, and graminoids are abundant (e.g., Carex atherodes, C. aquatilis). Freshwater marshes (EC $<500 \mu \mathrm{S} \mathrm{cm}{ }^{-1}$ ) are graminoid-or forb-dominated (various species of Carex, Scirpus, and/or Typha spp.), and have no mosses or occasional populations of Drepanocladus aduncus or Drepanocladus polygamus.

Fens: Minerotrophic peatlands with a ground layer of abundant bryophytes, and variable vegetation layers. Fens always have a ground layer of $90-100 \%$ cover of mosses, with either graminoid, shrub, and/or tree layers. Poor fens ( $\mathrm{pH}$ 4.5-5.5) are Sphagnum-dominated. Moderate-rich fens (pH [5.5]6.0-7.5) are brown moss-dominated, but often have large populations of mesotrophic Sphagnum species (Sphagnum fimbriatum, S. teres, S. squarrosum, S. subsecundum, or $S$ warnstorfii). Extreme-rich fens ( $\mathrm{pH} 7.5-8.5)$ are brown moss-dominated with no Sphagnum; however, rich fen site-types can have hummock development that lowers the $\mathrm{pH}$ and alkalinity in microhabitats. These microhabitats may have Tomentypnum nitens, Sphagnum warnstorfii, and even S. fuscum depending on the height of the hummocks. These 'mixed mires' are classified using the vegetation and chemistry of the hollow/lawn/carpet environment. Indicator species for the three fen types are shown in Fig. 3C.

Bogs: Ombrotrophic peatlands with or without trees in oceanic regions, scattered trees in sub-continental climates, or treed (open canopy) to forested (closed canopy) in continental climates, with a well-developed hummocky acrotelm and pools and carpets in oceanic climates, but with lawns and no pools in continental climates. Bogs are Sphagnumdominated, or in subarctic and northern boreal regions, they are feather moss-dominated, usually with abundant fruticose lichens and only sporadic occurrences of hummock species of Sphagnum. These feather moss-dominated sites are either the result of extensive permafrost development (peat plateaus), sporadic local permafrost often with collapse features, or mature bog sites with closed canopies and locally low water tables. At these sites, relatively dry conditions and reduction in the abundance of peat-forming bryophytes reduces the accumulation of peat.

Swamps: Shrubby, treed, or forested sites on organic soils with either shallow or sometimes locally deep peat layers. In western Canada, three types can be recognized based on nutrient status: 1) Oligotrophic (with black spruce (Picea mariana) or larch (Larix laricina) and a ground layer dominated by feather mosses and occasional populations of woodland sphagna (S. girgensohnii, S. squarrosum, S. russowii, or S. palustre). These sites are often transitional between upland and large peatland complexes, minerotrophic with circumneutral $\mathrm{pH}$, and lack ombrotrophic indicators (e.g., Sphagnum fuscum, Rubus chamaemorus). 2) Mesotrophic (with Salix-Betula shrubs). These sites transition to shrubby or graminoid fens, but with few bryophytes due to fluctuating water tables. 3) Eutrophic (with high herb diversity). These sites occur along small streams and riparian zones with abundant shade-tolerant bryophytes (species of Plagiomnium, Rhizomnium, Calliergon, Brachythecium, as well as assorted pleurocarpous species).

In summary, recognition of the individual wetland site-types is greatly enhanced by recognizing bryophyte functional groups, including Sphagnum, brown mosses, feather mosses, and shade-tolerant terrestrial species. Allogenic ecohydrologic gradients and ground layer autogenic modifications during development fundamentally control the distribution and abundance of wetland vegetation. In turn, the vegetation is one of the most important drivers for peat accumulation and carbon sequestration.

\section{Acknowledgments}

We thank the many field assistants that have provided invaluable help in data collecting and logistic support through many field seasons of field work in western Canada. Sandi Vitt provided the graphics for Figure 3 and is greatly appreciated. We are grateful to an anonymous reviewer who made helpful suggestions for improvement of the manuscript.

\section{References}

Bauer, I.E., Gignac, L.D. \& Vitt, D.H. (2003) Development of a peatland complex in boreal western Canada: lateral site expansion and local variability in vegetation succession and long-term peat accumulation. Canadian Journal of Botany 81: 833-847. https://doi.org/10.1139/b03-076

BRYOPHYTES AS INDICATORS AND STRUCTURE OF PEATLANDS

Bry. Div. Evo. 43 (1) (C) 2021 Magnolia Press • 261 
BFNA (2007, 2014) Flora of North America Vol. 27 Bryophyta part 1, vol. 28 Bryophyta part 2. Oxford University Press, New York and Oxford.

Birks, H.J.B., Line, J.M., Juggins, S., Stevenson, A.C. \& ter Braak, C.J.F. (1990) Diatoms and pH reconstruction. Philosophical Transactions of the Royal Society B, Biological Sciences 327: 263-278.

https://doi.org/10.1098/rstb.1990.0062

Bond-Lamberty, B., Wang, C. \& Gower, S.T. (2004) Net primary production and net ecosystem production of a boreal black spruce wildfire chronosequence. Global Change Biology 10: 473-487.

https://doi.org/10.1111/j.1529-8817.2003.0742.x

Bridgham, S.D., Pastor, J., Janssens, J.A., Chapin, C. \& Malterer, T.J. (1996) Multiple limiting gradients in peatlands: A call for a new paradigm. Wetlands 16: 45-65. https://doi.org/10.1007/BF03160645

Cajander, A.K. (1913) Studien über die Moore Finnlands. Acta Forestalia Fennica 2.3: 1-208. https://doi.org/10.14214/aff.7530

Campbell, I.D., Campbell, C., Yu, Z., Vitt, D.H. \& Apps. M.J. (2000) Millennial-scale rhythms in peatlands in the western interior of Canada and in the global carbon cycle. Quaternary Research 54: 155-158. https://doi.org/10.1006/qres.2000.2134

Caners, R.T. \& Lieffers, V.J. (2014) Divergent pathways of successional recovery for in situ oil sands exploration drilling pads on wooded, moderate-rich fens in Alberta, Canada Restoration Ecology 14: 657-667.

https://doi.org/10.1111/rec.12123

CCELC (1988) Canada Committee on Ecological (Biophysical) Land Classification, National Wetlands Working Group. Wetlands of Canada. Ecological Land Classification Series 24. Ottawa: Sustainable Development Branch, Canadian Wildlife Service, Conservation and Protection, Environment Canada.

du Reitz, G.E. (1942) De svenska fjällens växtvärld. Ymer 62: 169-190.

du Reitz, G.E.(1954)Die Mineralbodenwasserzeigergrenze als Grundlage einer natürlichen Zweigliederung der nord-und mitteleuropaischen Moore. Vegetatio 5-6: 571-585. https://doi.org/10.1007/BF00299611

Ellis, C.J. \& Rochefort, L. (2006) Long-term sensitivity of a High Arctic wetland to Holocene climate change. Journal of Ecology 94 : $441-454$. https://doi.org/10.1111/j.1365-2745.2005.01085.x

Esseen, P-A., Ehnström, B., Ericson, L. \& Sjoberg, K. (1997) Boreal forests. Ecological Bulletins 46: 16-47.

Fisher, T.G., Smith, D.G. \& Andrews, J.T. (2002) Preboreal oscillation caused by a glacial Lake Agassiz flood. Quaternary Sciences Reviews 21: 873-878. https://doi.org/10.1016/S0277-3791(01)00148-2

Fisher, T.G., Waterson, N., Lowell, T.V. \& I. Hajdas, I (2009) Deglaciation ages and meltwater routing in the Fort McMurray region, northeastern Alberta and northwestern Saskatchewan, Canada. Quaternary Science Reviews 28: 1608-1624. https://doi.org/10.1016/j.quascirev.2009.02.003

Freeman, C., Ostle, N. \& Kang, H. (2001) An enzymatic 'latch' on a global carbon store. Nature 409: 149. https://doi.org/10.1038/35051650

Halsey, L.A., Vitt, D.H. \& Bauer, I.E. (1998) Peatland initiation during the Holocene in continental western Canada. Climatic Change 40: 315-342. https://doi.org/10.1023/A:1005425124749

Gignac, L.D., Vitt, D.H., Zoltai, S.C. \& Bayley, S.E. (1991a) Bryophyte response surfaces along climatic, chemical and physical gradients in peatlands of western Canada. Nova Hedwigia 53: 27-71.

Gignac, L.D., Vitt, D.H. \& Bayley, S.E. (1991b) Bryophyte response surfaces along ecological and climatic gradients. Vegetatio 93: $29-45$.

Glaser, P.H. \& Janssens, J.A. (1986) Raised bogs in eastern North America: Transitions in landforms and gross stratigraphy. Canadian Journal of Botany 64: 395-415. https://doi.org/10.1139/b86-056

Goffinet, B., Buck, W.R. \& Shaw, A.J. (2008) Morphology, anatomy, and classification of the Bryophyta. In: Goffinet, B. \& Shaw, A.J. (Eds.) Bryophyte Biology: Second Edition. Cambridge University Press, Cambridge, pp. 55-138.

Gorham, E. \& Janssens, J.A. (1992) Concepts of fen and bog reexamined in relation to bryophyte cover and the acidity of surface waters. Acta Societatis Botanicorum Poloniae 61: 7-20. https://doi.org/10.5586/asbp.1992.001

Hedenäs, L. (2008) 61. Calliergonaceae. In: Flora of North America Editorial Committee (Org.) Flora of North America, Volume 28 
Bryophyta, part 2. Oxford University Press, New York and Oxford, pp. 384-403.

Hemond, H.F. (1980) Biogeochemistry of Thoreau's Bog, Concord, Massachusetts. Ecological Monographs 50: 507-526. https://doi.org/10.2307/1942655

Janssens, J.A. (1983) A quantitative method for stratigraphical analyses of bryophytes in Holocene peat. Journal of Ecology 71 : 189196.

https://doi.org/10.2307/2259971

Janssens, J.A., Hansen, B.C.S., Glaser, P.H. \& Whitlock, C. (1992) Development of a raised-bog complex. In: Wright, Jr., H.E., Coffin, B.A. \& Aaseng, N.E. (Eds.) The Patterned Peatlands of Minnesota. University of Minnesota Press. Minneapolis, MN, pp. 189221.

Kubiw, H., Hickman, M. \& Vitt, D.H. (1989) The developmental history of peatlands at Muskiki and Marguerite Lakes, Alberta. Canadian Journal of Botany 67: 3534-3544. https://doi.org/10.1139/b89-435

Kuhry, P. \& Vitt, D.H. (1996) Fossil carbon/nitrogen ratios as a measure of peat decomposition. Ecology 77: $271-275$. https://doi.org/10.2307/2265676

Kuhry, P., Halsey, L.A., Bayley, S.E. \& Vitt, D.H. (1992) Peatland development in relation to Holocene climatic change in Manitoba and Saskatchewan (Canada). Canadian Journal of Earth Sciences 29: 1070-1090.

https://doi.org/10.1139/e92-086

Kuhry, P., Nicholson, B.J., Gignac, L.D., Vitt, D.H. \& Bayley, S.E. (1993) Development of Sphagnum dominated peatlands in boreal continental Canada. Canadian Journal of Botany 71: 10-22.

https://doi.org/10.1139/b93-002

Loisel, J., Yu, Z.-C., Beilman, D.W., Philip, C., Alm, J., Amesbury, M.J., Anderson, D., Andersson, S., Bochicchio, C., Barber, K., Belyea, L.R., Bunbury, J., Chambers, F.M., Charman, D.J., De Vleeschouwer, F., Fiałkiewicz-Kozieł, B., Finkelstein, S.A., Gałka, M., Garneau, M., Hammarlund, D., Hinchcliffe, W., Holmquist, J., Hughes, P., Jones, M.C., Klein, E.S., Kokfelt, U., Korhola, A., Kuhry, P., Lamarre, A., Lamentowicz, M., Large, D., Lavoie, M., MacDonald, G., Magnan, G., Mäkilä, M., Mallon, G., Mathijssen, P., Mauquoy, D., McCarroll, J., Moore, T.R., Nichols, J., O’Reilly, B., Oksanen, P., Packalen, M., Peteet, D., Richard, P.J.H., Robinson, S., Ronkainen, T., Rundgren, M., Sannel, A.B.K., Tarnocai, C., Thom, T., Tuittila, E.-S., Turetsky, M., Väliranta, M., van der Linden, M., van Geel, B., van Bellen, S., Vitt, D., Zhao, Y. \& Zhou, W.-J. (2014) A database and synthesis of northern peatland soil properties and Holocene carbon and nitrogen accumulation. The Holocene 24: 1028-1042.

https://doi.org/10.1177/0959683614538073

Maltby, E. \& Immirzi, P. (1993) Carbon dynamics in peatlands and other wetland soils, regional and global perspectives. Chemosphere 27: 999-1023.

https://doi.org/10.1016/0045-6535(93)90065-D

Moore, T.R. (1989) Growth and net production of Sphagnum at five fen sites, subarctic eastern Canada. Canadian Journal of Botany 67: 1203-1207. https://doi.org/10.1139/b89-156

Nicholson, B.J. \& Vitt, D.H. (1994) Wetland development at Elk Island National Park, Alberta, Canada. Journal of Paleolimnology 12: $19-34$.

https://doi.org/10.1007/BF00677987

Pouliot, R., Rochefort, L. \& Gauthier, G. (2009) Moss carpets constrain the fertilizing effects of herbivores on graminoid plants in arctic polygon fens. Botany 87: 1209-1222.

https://doi.org/10.1139/B09-069

Pouliot, R., Rochefort, L., Karofeld, E. \& Mercier, C. (2011) Initiation of Sphagnum moss hummocks in bogs and the presence of vascular plants: Is there a link? Acta Oecologica 37: 346-354.

https://doi.org/10.1016/j.actao.2011.04.001

Reimer, P.J., Ballie, M.G.L., Bard, E., Bayless, A., Beck, J.W., Blackwell P.G., Ramsey, C.B., Buck, C.E., Burr, G.S., Edwards, R.L., Friedrich, M., Grootes, P.M., Guilderson, T.P., Hajdas, I., Heaton, T.J., Hogg, A.G., Hughen, K.A., Kaiser, K.F., Kromer, B., McCormac, F.G., Manning, S.W., Reimer, R.W., Richards, D.A., Southon, J.R., Talamo, S., Turney, C.S.M., van der Plicht, J. \& Weyhenmeyer, C.E. (2009) IntCal09 and marine09 radiocarbon age calibration curves, 0-50,000 years cal BP. Radiocarbon 51: 1111-1150. https://doi.org/10.1017/S0033822200034202

Richards, P.W. (1984) Chapter 21. The ecology of tropical forest bryophytes. In: Schuster R.M. (Ed.) New Manual of Bryology. Hattori Botanical Laboratory, Nichinan, Japan, pp. 1231-1270.

Sjörs, H. (1950) Regional studies in north Swedish mire vegetation Botanische Notiser 1950: 174-221.

Sjörs, H. (1952) On the relations between vegetation and electrolytes in north Swedish mire waters. Oikos 2.2: 242-258. 
https://doi.org/10.2307/3564795

Sjörs, H. (1983) Mires of Sweden. In: A.J.P. Gore (Ed.) Ecosystems of the World 4B. Elsevier Scientific Publishing Company, Amsterdam, Netherlands, pp. 69-94.

Startsev, N., Lieffers, V.J. \& Landhausser, S.M. (2008) Effects of leaf litter on the growth of boreal feather mosses: Implication for forest floor development. Journal of Vegetation Science 19: 253-260. https://doi.org/10.3170/2008-8-18367

Vitt, D.H. (1994) An overview of factors that influence the development of Canadian peatlands. Memoirs of the Entomological Society of Canada 169: 7-20. https://doi.org/10.4039/entm126169007-1

Vitt, D.H. (2006) Functional characteristics and indicators of boreal peatlands. In: Wieder, R.K. \& Vitt, D.H. (Eds.) Boreal Peatland Ecosystems. Springer-Verlag, Berlin-Heidelburg-New York, pp. 9-24. https://doi.org/10.1007/978-3-540-31913-9_2

Vitt, D.H. (2014) A key and review of bryophytes common in North American peatlands. Evansia 31: 121-156. https://doi.org/10.1639/079.031.0402

Vitt, D.H. \& Chee, W.-L. (1990) The relationships of vegetation to surface water chemistry and peat chemistry in fens of Alberta, Canada. Vegetatio 89: 87-106. https://doi.org/10.1007/BF00032163

Vitt, D.H. \& Lüth, M. (2017) A Guide to the Mosses and Liverworts of Alberta Peatlands. Digital publication available on Research Gate.

Vitt, D.H., Halsey, L.A. Bray, J. \& Kinser, A. (2003) Patterns of bryophyte richness in a complex boreal landscape: Identifying key habitats at McClelland Lake wetland. The Bryologist 106: 372-382. https://doi.org/10.1639/03

Vitt, D.H., House, M. Kitchen, S. \& Wieder R.K. (2020) A protocol for monitoring plant responses to changing nitrogen deposition regimes in Alberta bogs. Environmental Monitoring and Assessment (accepted Sept. 2020).

https://doi.org/10.1007/s10661-020-08645-z

Weber, C. (1911) Das Moore. Hannoversche Geschichtsbericht 14: 255-270.

Wheeler, B.D. \& Proctor, M.C.F. (2002) Ecological gradients, subdivisions and terminology of north-west European mires. Journal of Ecology 88: 187-203. https://doi.org/10.1046/j.1365-2745.2000.00455.x

Wieder R.K., Vitt, D.H. \& Benscoter, B. (2006) Peatlands and the boreal forest. In: Wieder, R.K. \& Vitt, D.H. (Eds.) Boreal Peatland Ecosystems. Springer-Verlag, Berlin-Heidelburg-New York, pp. 1-8. https://doi.org/10.1007/978-3-540-31913-9_1

Williams, C.J., Yavitt, J.B., Wieder, R.K. \& Cleavitt, N.L. (1998) Cupric oxide oxidation products of northern peat and peat forming plants. Canadian Journal of Botany 76: 51-62. https://doi.org/10.1139/b97-150

Xu, J., Morris, P.J., Liu, J. \& Holden, J. (2018) PEATMAP: Refining estimates of global peatland distribution based on a metaanalysis. Catena 160: 134-140. https://doi.org/10.1016/j.catena.2017.09.010

Yu, Z., Campbell, I.D., Campbell, C., Vitt, D.H., Bond, G.C. \& Apps, M.J. (2003) Carbon sequestration in western Canadian peat highly sensitive to Holocene wet-dry climate cycles at millennial timescales. The Holocene 13: 801-808. https://doi.org/10.1191/0959683603hl667ft

Yu, Z., Loisel, J. Brosseau, D.P., Beilman, D.W. \& Hunt, S.J. (2010) Global peatland dynamics since the last Glacial Maximum. Geophysical Research Letters 37: L13402.

https://doi.org/10.1029/2010GL043584

Yu, Z., Vitt, D.H. \& Wieder, R.K. (2014) Continental fens in western Canada as effective carbon sinks during the Holocene. The Holocene 24: 1090-1104. https://doi.org/10.1177/0959683614538075 